The most widely read and highly cited peer-reviewed neurology journal The Official Journal of the American Academy of Neurology

\title{
Teaching NeuroImage: Fasting EEG in Glucose Transporter-1 Deficiency Syndrome
}

Author(s):

Hassan Imtiaz, MD ${ }^{1}$; Afra Can, MD ${ }^{1}$; Daniela Tapos, MD ${ }^{1}$; Amanda Weber, DO ${ }^{1}$

Corresponding Author:

Hassan Imtiaz

dr.hassanimtiaz@hotmail.com

Neurology® Published Ahead of Print articles have been peer reviewed and accepted for publication. This manuscript will be published in its final form after copyediting, page composition, and review of proofs. Errors that could affect the content may be corrected during these processes. 
Affiliation Information for All Authors: 1. Wayne State University, Detroit, Michigan

\section{Contributions:}

Hassan Imtiaz: Drafting/revision of the manuscript for content, including medical writing for content; Major role in the acquisition of data; Analysis or interpretation of data

Afra Can: Drafting/revision of the manuscript for content, including medical writing for content; Major role in the acquisition of data

Daniela Tapos: Drafting/revision of the manuscript for content, including medical writing for content; Major role in the acquisition of data

Amanda Weber: Drafting/revision of the manuscript for content, including medical writing for content;

Major role in the acquisition of data; Analysis or interpretation of data

Number of characters in title: 59

Abstract Word count:

Word count of main text: 100

References: 2

Figures: 1

Tables: 0

Neuroimage Legend Count: 44

Search Terms: [ 283 ] All clinical neurophysiology, [ 284 ] EEG; see Epilepsy/Seizures (S), [ 63 ] Epilepsy monitoring, [ 163 ] Gait disorders/ataxia, [ 170 ] Chorea

Study Funding: The authors report no targeted funding

Disclosures: The authors report no disclosures relevant to the manuscript.

A 12 year old male presented for evaluation of chorea induced by fasting and exercise. EEG,

Brain MRI, spectroscopy, metabolic and microarray evaluations were unremarkable. Fasting EEG showed diffuse spike-wave discharges with postprandial normalization (Figure 1); chorea was not captured. Genetic testing confirmed a pathogenic SLC2A1 mutation consistent with Glucose transporter-1 (GLUT-1) deficiency syndrome, which is uniquely responsive to ketogenic diet. EEG findings in this syndrome may include multifocal or generalized spikes, with postprandial improvement $(1,2)$. This case suggests a supportive role for fasting EEG in the diagnosis of Glucose transporter-1 deficiency syndrome, but the sensitivity and specificity remain unclear. 
[AZ 11.12.2021] 175053 Teaching Slides -- http://links.lww.com/WNL/B689

\section{$\underline{\text { References: }}$}

1. Koch, H., Weber, Y. G. The glucose transporter type 1 (Glut1) syndromes. Epilepsy \& Behavior 2018; 91:90-93.

2. VonMoers A, Brockman K, Wang D, et al. EEG features of Glut-1 deficiency syndrome. Epilepsia 2002; 43(8): 41-5.

\section{Ethical Compliance Statement:}

The authors confirm that the approval of an institutional review board was not required for this work. We confirm that the inform consent was obtained from the parents. We confirm that we have read the Journal's position on issues involved in ethical publication and affirm that this work is consistent with those guidelines. 
Figure 1: EEG during fasting (A, B) showing diffuse, poorly-formed 3-4 Hz spike-wave discharges. EEG after meal $(\mathrm{C}, \mathrm{D})$ showing background normalization. This EEG is shown on a 15-second epoch with a sensitivity of $7 \mu \mathrm{V}$ in a longitudinal bipolar montage, left over right.
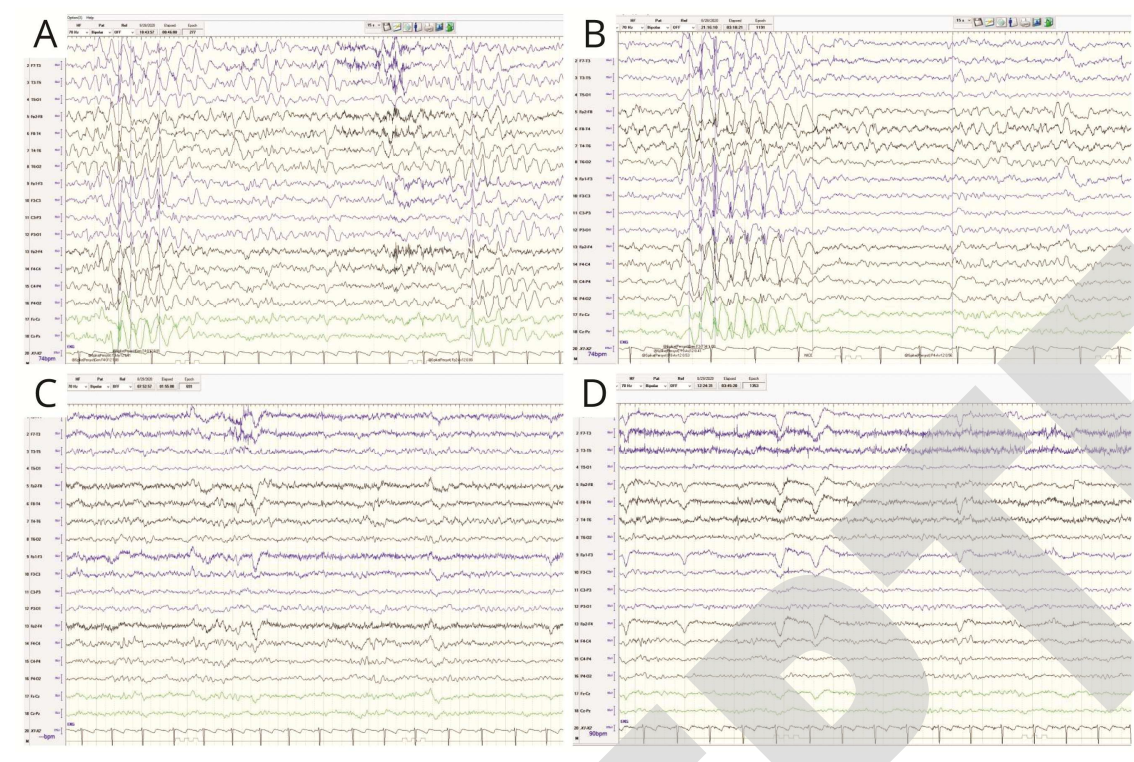
D $\cdots-\cdots=$

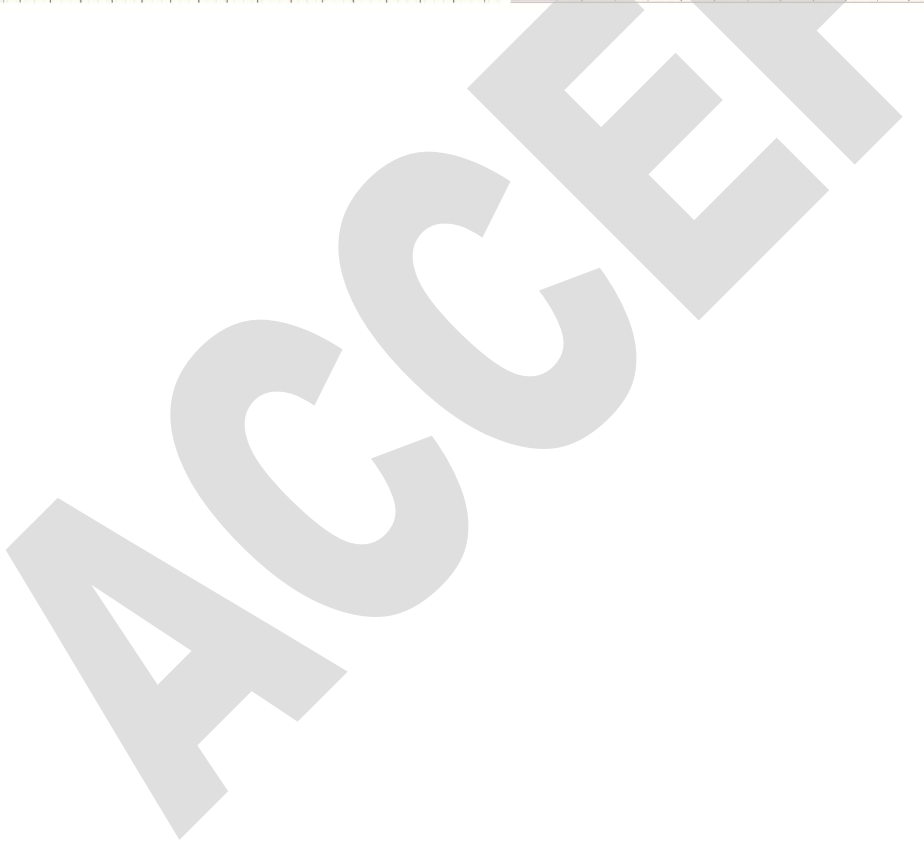




\section{Neurology}

\section{Teaching NeuroImage: Fasting EEG in Glucose Transporter-1 Deficiency Syndrome}

Hassan Imtiaz, Afra Can, Daniela Tapos, et al.

Neurology published online December 3, 2021

DOI 10.1212/WNL.0000000000013143

This information is current as of December 3, 2021

Updated Information \&

Services

Subspecialty Collections

Permissions \& Licensing

Reprints including high resolution figures, can be found at:

http://n.neurology.org/content/early/2021/12/02/WNL.0000000000013143. citation.full

This article, along with others on similar topics, appears in the following collection(s):

All clinical neurophysiology

http://n.neurology.org/cgi/collection/all_clinical_neurophysiology

Chorea

http://n.neurology.org/cgi/collection/chorea

EEG; see Epilepsy/Seizures

http://n.neurology.org/cgi/collection/eeg_see_epilepsy-seizures

Epilepsy monitoring

http://n.neurology.org/cgi/collection/epilepsy_monitoring_

Gait disorders/ataxia

http://n.neurology.org/cgi/collection/gait_disorders_ataxia

Information about reproducing this article in parts (figures,tables) or in its entirety can be found online at:

http://www.neurology.org/about/about_the_journal\#permissions

Information about ordering reprints can be found online:

http://n.neurology.org/subscribers/advertise

Neurology ${ }^{\circledR}$ is the official journal of the American Academy of Neurology. Published continuously since 1951, it is now a weekly with 48 issues per year. Copyright (C) 2021 American Academy of Neurology. All rights reserved. Print ISSN: 0028-3878. Online ISSN: 1526-632X.

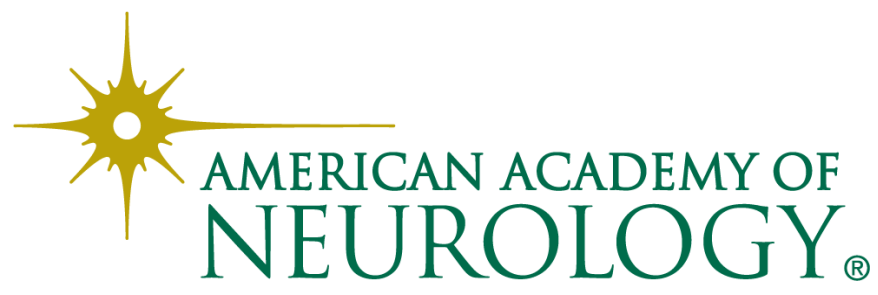

